\title{
Research on the Application of Innovative Thinking Training Method in Environmental Design Specialty Teaching
}

\author{
Li jun
}

City College, Wuhan University of Science and Technology, Wuhan, China

awi2523@163.com

\begin{abstract}
Keywords: Application, Innovative Thinking Training Method, Environmental Design Specialty Teaching
\end{abstract}

\begin{abstract}
Art design reflects the form and aesthetics of art in many aspects of society, culture, economics, science and technology, and makes it not only have the aesthetic function but also have the function of using it. Art design first is to serve people, big space environment, small clothing, food, shelter, transportation, use and so on. Art design should be the perfect combination of certain material and spiritual functions in human society. Along with the development of the times, art and design should not only meet people's material needs, but also meet contemporary aesthetic and even humanistic needs. This also forces art education to innovate on the basis of the existing technical education. Thinking training has become the core of art design education. In recent years, all major design institutes have injected innovative thinking training into the curriculum of design education to meet the market demand under the new social situation.
\end{abstract}

\section{Introduction}

With the continuous development of the industry, new demands are placed on the teaching of environmental design specialty. The innovation ability of students depends entirely on the thinking of students. The essence of design is innovation. This is also the teaching goal of colleges and universities at present stage. Many colleges and universities stress too much professional theory of learning, hands-on and professional skills training basically neglected, leading to the majority of students in the school basically did not learn how much useful things, but also in the community to use very little, let alone what innovation. Therefore, as a member of the education sector, I hope I can change the status quo at that time so that the students' thinking is not rigid and short-sighted. We should cultivate and innovate the students who lack creativity in teaching at an appropriate time and in an advantageous environment Improvement and innovative design concepts are all important issues that our colleges and universities should urgently need to solve.

\section{The Environmental Design Professional Disciplines}

The indoor environment design profession involves a wide range of aspects, not only related to the humanities, history and economy, but also makes a great contribution to people's living environment and quality of life improvement. Specific features are the following aspects:

Environmental design is a wide range of popular design, practical subjects, is to serve the creative aspects of society to meet people's growing material and spiritual needs. Interior design environment from the old teaching mode gradually changed to meet the increasingly fierce market demand. Colleges and universities to enable students to participate in practice, the theoretical knowledge and practice learned to combine closely to improve the practical ability of students, it is highly practical.

Environmental design is also a discipline that requires strong creativity. It is a process in which teachers and students learn together. They focus on training professional and practical skills, cultivating students' sense of innovation and adapting design talents to the needs of society. Whether it is a theoretical lesson, practical lesson, this ability to train students should be run through. To guide students to pay attention to the cultivation of innovative awareness, understanding the hardships of the creative process, interact with the teacher in the classroom, how 
to make their own capabilities These are slowly tapped, need to pay off and continue to broaden their horizons, exposure to fresh Things and more to read some foreign design work, and constantly improve themselves in order to create a more perfect design work.

Environmental design changes with the development of the times accordingly, which shows that it is not static, is constantly changing, so it is dynamic. Environmental design requires that we constantly update our thinking. Teachers constantly update their teaching programs and professional teaching techniques so that students will experience different classrooms. As a result, students will have a great improvement in guidance and vision. Unique design concept is also by designers constantly updated their knowledge reserves, grasp the pace of the times, using what we learned, so as to continuously improve people's cognitive ability of the design work.

\section{The Main Content of Innovative Thinking Training}

Design comes from life and above life. As a result of production, life, worship and aesthetic needs, our ancestors created a series of products that met the needs of the time. So the design first appeared in people's lives and served the people's life. With the economic development, the primary task of a designer is to have the clearest understanding of the pace of social development. However, this cognitive activity requires its full devotion to the course of social development. Offering art design courses at university helps students develop a deep understanding of the nature of design, the relationship between design and humanity, and how to use creative thinking to design art.

In the traditional design teaching, teachers often simply train innovative thinking through this basic design teaching, such as the form training in the plane composition, the color and psychology in the color composition, etc., teaching students some form and color, confined the development of divergent thinking students. In the course of sample survey, the author found that students tend to attach a common label to the characteristics of a thing, and this knowledge of mechanization makes students think in the form of a single design work, nothing new at all.

The purpose of setting up innovative thinking training courses is to give students more opportunities to subjectively know the world so that they can use their own emotions, life experiences and worldviews to feel the world and use the means of design to represent the world. Therefore, the conversion of the mode of thinking plays an extremely important role in the whole teaching process. Teachers should guide students to think actively, understand the external things and learn feelings first; second, convert the image thinking into the design mode of thinking; finally, Terminal for the market service, which is the main content of thinking training.

\section{The Role of Innovative Thinking Training}

Students at the beginning of art and design learning first conducted a series of basic courses and these courses develop students' solid basic skills. The purpose of basic training is to enable students to understand the expression of artistic creation. If the basic training is to develop students' understanding of tools, then thinking training is to train students to use tools. In the traditional basic course teaching, the design sketch course is the most common pencil, charcoal and other tools, students seem to get used to this single mode of expression, the understanding of the material tools is far from enough, students often do not know what to do after leaving these tools However, this single form of teaching is difficult to fit the core of design teaching. In the training of thinking teachers can guide students to use a single color performance of different design ideas and broaden students' design ideas. Appropriate to break the conventional mode of thinking can mobilize the students' thinking and thinking can bring a kind of vitality for the mode of expression means. Therefore, in basic teaching, students can greatly expand the creative thinking through various materials and various forms of expression, such as rubbing, collage, breaking up, painting, monochrome, multi-color, etc. are all effective express means. In short, in the teaching process, teachers should guide students to use innovative methods to express their design ideas, so as to enable students to enter a state of self-expression. Design-based teaching is also very important in guiding students to express artistic design. 
As we all know, art design is a product of the combination of science and art. Therefore, design thinking at the level of thinking necessarily includes scientific thinking and artistic thinking. Scientific thinking and artistic thinking can also be called logical thinking and visual thinking. We call the design thinking needs to use scientific thinking and artistic thinking to organize and explain, but also the need for the participation of the image of thinking. However, no matter how these three are combined in the process of design thinking, all of them should reflect the creative activities of designers. The core of design thinking is creative thinking. Creative thinking is a way to break the routine, pioneering and innovative thinking, there is no creative thinking of the development of modern design. The whole process of design activity is to create a creative design ideas and the final design of the production process of the product, we can easily see that the advent of each outstanding design work accompanied by the emergence of creative thinking. Therefore, in the process of teaching, in addition to teaching students to design products, students should be better informed about the development of the entire design and product ideas and ideas. For example, students deal with the simple forms of natural forms by means of aesthetics of aesthetics, and put their own understanding of things and divergent thinking training, which is conducive to developing observation skills and understanding the core of design. The design education in colleges and universities needs to train students' design thinking so that students can use creative thinking to express their own design ideas and convey more innovative talents for the development of modern design.

\section{The Ways to Develop Students' Innovative Thinking}

The so-called change, in fact, is to allow students to change from passive acceptance to active thinking, students 'innovative thinking as the mainstay to develop students' consciousness of innovation, to discard the negative factors that are not conducive to the cultivation of innovative ability. Teaching can try to make students more involved, more contact with new things, from passive acceptance to active participation, not only increased the enthusiasm of students to learn, but also allow students to think independently and guide students to learn the design of the relevant cases, pointed out its inadequacies, how to correct, etc., will allow students to learn the importance of thinking to solve the problem, this approach has been proven that students will become passive and active, and creative thinking has been a good exercise.

Students in the learning process, and constantly strengthen their own ability to learn more professional knowledge, over time experience increased slowly, to grasp most of the core information, can help to make a qualitative leap in thinking, as a teacher should guide students correctly Jumping out of inertia thinking, continuous updating of knowledge reserves, to give students the right guidance. How to finish creative thinking we have to a large extent implement some solutions, for example, from teaching and designing the two aspects of comprehensively cultivate students, quantify the results of both, so that students also learn to enhance the design inspiration , pointed out that its design flaws, in the next design concept to be amended, so that by slowly correcting and perfecting, so that students left a deep impression, to break through the design of the direct results of the model, in the early design of a design program Series of reasoning, analysis, the process of timely leak fill vacancies, so that through the design of students in the process of thinking and improve the perfect thinking gives the final result, I think this study should be applied in colleges and universities.

\section{Conclusion}

With the continuous improvement of society, the rapid development of the construction industry, the increasing demand for innovative talents in the society, the training of innovative thinking of students in colleges and universities is also very crucial, and many colleges and universities have also introduced some management measures. The essence is to train more innovative talents who adapt to the society should be better prepared as educators. This is not only the needs of students but also the needs of the community. Ten years of trees, the concept of a hundred years of trees is 
that we should deeply understand. To this end, it is a long way to go. We must make continuous progress in seeking more and more Chinese designers in foreign designs.

\section{References}

[1] Chen Junying. Research on the New Countryside Environment Art Design [J]. Art Design. 2017 (06)

[2] Song Xiaofeng, Chen Xiaoming. On environmental art design awareness [J]. Jilin Architectural Design. 1997 (02)

[3] Lin Zejun. On the image design sketches the performance of texture replacement [J]. Art Education, 2010.

[4] Han Cong. On the ecological concept of environmental art design [J]. Daily love science. 2016 (18)

[5] Yang Qiong. On the ecological concept of environmental art design [J]. Tomorrow fashion 2017 (09)

[6] Teng Xuerong. Environmental Art Design Policy [J]. China Construction Education. 2007 (06)

[7] Jiang Bo. Analysis of eco-concept in environmental art design [J]. Art Kam 2017 (06) 